\title{
UJI AKTIFITAS ANTIBAKTERI EKSTRAK ETANOL KULIT BUAH MANGGIS (Gracinia mangostana L.) TERHADAP PERTUMBUHAN BAKTERI Escherichia coli
}

\section{(ANTIBACTERY TEST ACTIVITY OF ETHANOL EXTRACT MANGGIS LEAVES (Gracinia mangostana L.) ON GROWTH OF BACTERIA Escherichia coli)}

\author{
Putri Permata*, Retno Kawuri, A.A. Ketut Darmadi \\ Program Studi Biologi Fakultas MIPA, Universitas Udayana, Bali \\ *Email: putrikpermata@gmail.com
}

\section{INTISARI}

Kulit manggis mempunyai senyawa yang terkandung yaitu xanthone yang meliputi mangostin, mangosterol, mangostinon A dan B, trapezifolixanthone, tovophyllin B, alfa dan beta mangostin, garcinon B, mangostanol, gartanin, dan flavonoid epikatekin yang diketahui bersifat antibakteri dan antidiare. Escherichia coli merupakan bakteri yang banyak ditemukan di dalam usus besar manusia sebagai flora normal. Sifatnya unik karena dapat menyebabkan infeksi primer pada usus misalnya diare pada anak, menimbulkan infeksi pada jaringan tubuh lain diluar usus. Penelitian dilakukan pada bulan Desember 2016-Maret 2017. Metode yang dipergunakan, yaitu metode sumur difusi untuk mengetahui daya hambat dengan cara mengukur zona bening yang terbentuk. Uji kandungan senyawa ekstrak menggunakan uji skrining fitokimia. Data yang didapat akan dalam penelitian dianalisis menggunakan analysis of variance (ANOVA). Pada uji daya hambat ekstrak etanol kulit buah manggis (G. mangostana L.) dapat menghambat pertumbuhan bakteri Escherichia coli secara invitrodengan daya hambat sebesar $1,58 \mathrm{~cm}$ dan dikategorikan sebagai daya hambat yang kuat, dengan MIC yaitu 3,9\% dan senyawa yang terkandung pada ekstrak etanol kulit manggis (G. mangostana L.) adalah alkaloid, fenolik, flavonoid, saponin dan terpenoid.

Kata kunci : aktifitas antibakteri, Garcinia mangostana L., Escherichia coli.

\section{ABSTRACT}

Mangosteen rind has a benefical compounds liked xanthone which consisting of mangostin, mangosterol, mangostinon $\mathrm{A}$ and $\mathrm{B}$, trapezifolixanthone, tovophyllin $\mathrm{B}$, alpha and beta mangostin, garcinon B, mangostanol, gartanin, and flavonoid epikatekin that known contain an antibacterial and antidiare agent. Escherichia coliis an opportunistic bacterium that is commonly found in the human colon as a normal flora. Its unique because it can cause primary infection in the intestine such as diarrhea in children, as well as its ability to cause infection in other body tissues outside the intestine.This research was done from December 2016 to March 2017. The methods that used in this research were well diffusion test to know the inhibitory power by measuring the clear zone formed. measure the clear zone of mangosteen rind against Escherichia coli. Then to testing extract compounds, there was used phytochemicals screening test. Data there has been found will be analyzed through analysis of variance (ANOVA). In the inhibitory test of ethanol extract from mangosteen rind $(G$. mangostana L.), it was so effective to inhibit the growth of Escherichia coli through in-vitro test with a resistivity of 1,58 $\mathrm{cm}$ and categorized as a strong inhibitory, which MIC from mangosteen rind against Escherichia coli was 3,9\% and the compounds that contain in ethanol extract from mangosteen rind (G. mangostana L.) were alkaloid, phenolik, flavonoid, saponin and terpenoid.

Key word : antibacterial activity, Garcinia mangostana L., Escherichia coli..

\section{PENDAHULUAN}

Pemanfaatan kulit buah manggis (Gracinia mangostana L.) di Indonesia banyak dikembangkan oleh masyarakat luas untuk peremajaan kulit atau sebagai zat warna untuk makanan dan industri kecil. Selain itu kulit manggis juga sangat bermanfaat sebagai antibakteri, rebusan kulit buah manggis dikatakan memiliki efek anti diare (Cahyo dan Agus, 2011).

Menurut Qosim (2007), kulit buah manggis sudah menjadi ramuan tradisional turun temurun untuk mengobati infeksi pada kulit, luka dan diare. Bahkan di negara seperti di Amerika Serikat, kulit manggis sudah menjadi suplemen diet yang dianjurkan oleh Food and Drug Administration (FDA) atau Badan Pengawas Obat dan Makanan Pemerintah Amerika Serikat karena potensial sebagai antioksidan.

Hasil penelitian ilmiah menyebutkan bahwa kulit buah Manggis sangat kaya akan anti-oksidan. Secara umum, kandungan kimia yang paling banyak terdapat dalam kulit manggis adalah xanthone, antosianin, flavonoid, dan tannin (Dungir et al., 2012).Penelitian lain yang dilakukan oleh Noviardini (2010), menunjukkan bahwa aktivitas antibakteri senyawa alfa mangostin kulit buah manggis (Garcinia mangostana L.) dapat menghambat pertumbuhan bakteri Escherichia coli dan bakteri Streptococcus sp. Namun belum terdapat penelitian tentang aktivitas antibakteri ekstrak etanol terhadap E. coli.

\section{METODE PENELITIAN}

Penelitian akan dilakukan di Laboratorium Mikrobiologi Program Studi Biologi Fakultas Matematika dan Ilmu Pengetahuan Alam Universitas Udayana, Bukit, Jimbaran. Penelitian dilakukan dari bulan November 2016 hingga April 2017. Buah manggis diambil dari wilayah Desa Munduktemu, Kecamatan Pupuan, Kabupaten Tabanan sebanyak $3 \mathrm{~kg}$. Kreteria sampel kulit yaitu, kulit yang segar atau tidak mengkerut, sudah berwarna merah keunguan, dan tidak adanya pembusukan. Rancangan yang dipergunakan dalam penelitian ini adalah rancangan acak lengkap (RAL) dengan menggunakan 6 perlakuan dan 4 kali ulangan pada uji Minimum Inhibitory Concentration(MIC). Data yang didapat akan dalam penelitian dianalisis menggunakan analysis of variance (ANOVA). Metode yang dipergunakan dalam penelitian ini, yaitu metode 


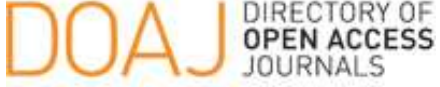

sumur difusi untuk mengukur zona bening yang terbentuk agar bisa dipergunakan dalam menentukan MIC dan aktifitas antibakteri dari ekstrak kulit manggis terhadap bakteri Escherichia coli.

\section{HASIL}

Uji daya hambat ekstrak kasar kulit buah manggis (Garcinia mangostana L.) pada bakteri uji Escherichia coli
Hasil uji daya hambat ekstrak kulit manggis (Garcinia mangostana L.) menunjukkan bahwa pemberian ekstrak mampu menghambat pertumbuhan dari bakteri E. coli (Gambar 1.). Daya hambat terbesar terdapat pada pengulangan dengan kode $\mathrm{P} 3$ yaitu sebesar $1,58 \mathrm{~cm}$ pada masa inkubasi selama 24 jam dan sebesar $1,61 \mathrm{~cm}$ pada masa inkubasi 48 jam. (Tabel 1.).

Tabel 1 Diameter rata - rata daya hambat ekstrak kasar kulit manggis (G. mangostana L.) terhadap bakteri E. coli.

\begin{tabular}{cccc}
\hline \multirow{2}{*}{ Konsentrasi } & $\begin{array}{c}\text { Kode } \\
\text { Pengulangan }\end{array}$ & \multicolumn{2}{c}{ Diameter Daya Hambat } \\
\cline { 3 - 4 } & & $\mathbf{2 4}$ jam & $\mathbf{4 8}$ jam \\
& P1 & 1,38 & 1,40 \\
\hline \multirow{2}{*}{$100 \%$} & $\mathrm{P} 2$ & 1,50 & 1,53 \\
& $\mathrm{P} 3$ & 1,58 & 1,61 \\
Rata - rata & & 1,48 & 1,51 \\
\hline
\end{tabular}

Daya hambat terkecil (MIC) dari ekstrak kulit manggis (Garcinia mangostana L.) pada bakteri Escherichia coli

Hasil uji Minimum Inhibitory Concentration (MIC) ekstrak kulit manggis (G. mangostana L.) pada bakteri $E$. coli menunjukkan bahwa konsentrasi ekstrak kulit manggis yang paling terkecil menghambat yaitu pada konsentrasi 3,9 \% (Gambar 3).

Efektivitas daya hambat ekstrak kulit manggis (G. mangostana L.) terhadap pertumbuhan E. coli terdapat 6 (enam) konsentrasi yang di ujikan dan 4 ulangan. Adapun konsentrasi yang di uji yaitu konsentrasi $0 \% ; 3,9 \% ; 4 \% ; 4,1 \% ; 4,2 \% ;$ dan $4,3 \%$.
Perlakuan dengan konsentrasi $3,9 \% \quad(b / v)$ memberikan daya hambat dengan diameter hambat sebesar $0,98 \mathrm{~cm}$, sedangkan pada perlakuan dengan 4,3\% memberikan dayahambat dengan diameter hambatan 1,07 $\mathrm{cm}$ (Tabel 2.). Hasil penelitian ini memperlihatkan adanya hubungan yang erat antara konsentrasi ekstrak kulit manggis dengan daya hambat terhadap pertumbuhan bakteri E. coli (Gambar 1. dan Gambar 4.).

Hasil uji Minimum Inhibitory Concentration (MIC) ekstrak kulit manggis (G. mangostana L.) pada bakteri E. coli menunjukkan bahwa konsentrasi ekstrak kulit manggis yang paling terkecil menghambat yaitu pada konsentrasi 3,9\%.

Tabel 2. Daya hambat ekstrak kulit manggis (Garcinia mangostana L.) terhadap pertumbuhan bakteri Escherichia coli pada 6 perlakuan dan 4 ulangan.

\begin{tabular}{ccc}
\hline Konsentrasi (\%) & N & $\begin{array}{c}\text { Rata }- \text { rata zona hambat }(\mathrm{cm}) \pm \\
\text { Standar Deviasi }\end{array}$ \\
\hline $0 \%$ & 4 & $0 \pm 0,00000 \mathrm{a}^{*}$ \\
$3,9 \%$ & 4 & $0,9875 \pm 0,02500 \mathrm{~b}$ \\
$4 \%$ & 4 & $1 \pm 0,00000 \mathrm{~b}$ \\
$4,1 \%$ & 4 & $1,0075 \pm 0,07890 \mathrm{bc}$ \\
$4,2 \%$ & 4 & $1,0575 \pm 0,01500 \mathrm{~cd}$ \\
$4,3 \%$ & 4 & $1,0775 \pm 0,02062 \mathrm{~d}$ \\
\hline
\end{tabular}

Keterangan :

*Nilai pada Tabel 2 merupakan \pm standar deviasi dari rata - rata 4 kali ulangan dengan notasi huruf pada kolom yang berbeda menunjukkan bahwa perlakuan berbeda nyata $(\mathrm{P}<0,05)$.

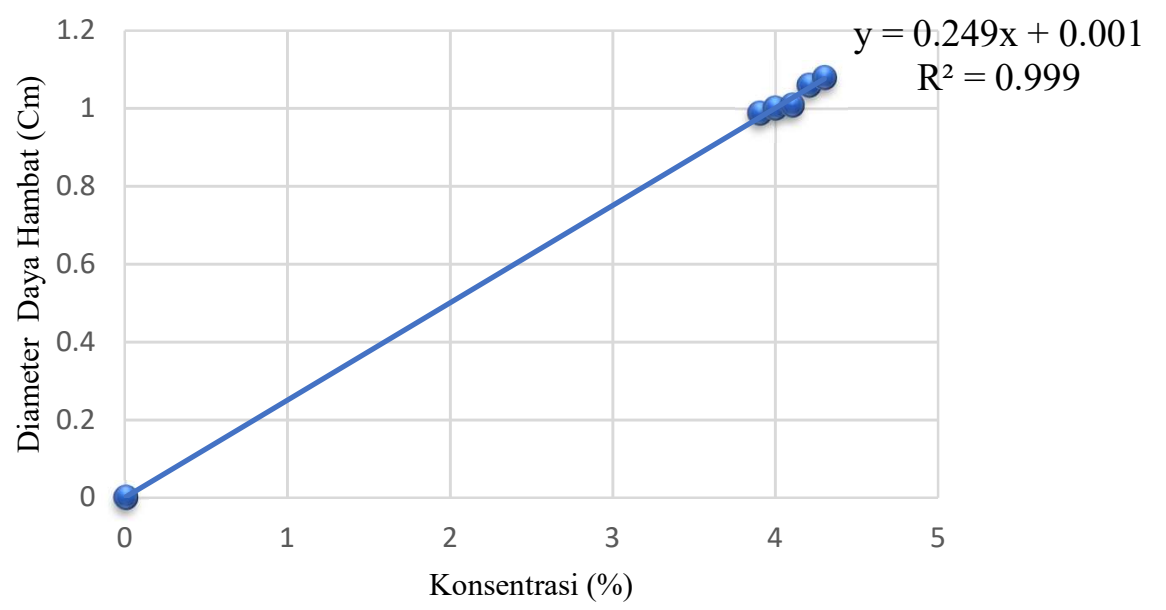

Gambar 1. Grafik hubungan antara konsentrasi ekstrak kulit manggis G. mangostana L.) dengan daya hambat ekstrak kulit manggis terhadap pertumbuhan koloni bakteri E. Coli (MIC). 


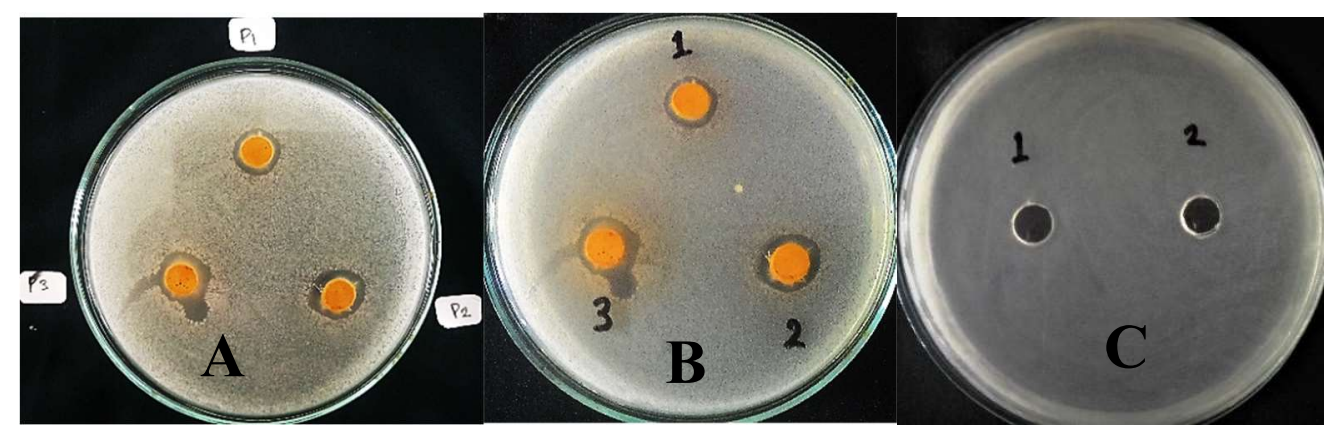

Gambar 2. Daya hambat ekstrak kasar kulit manggis (G. mangostana L.) terhadap bakteri E. coli usia 24 jam (A), 48 jam (B) dan kontrol negatif berupa pelarut etanol (C).

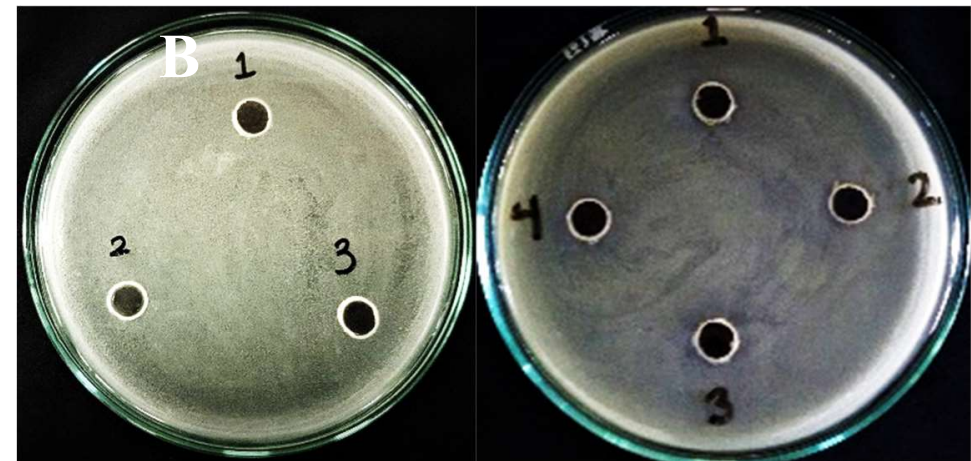

Gambar 3. Daya hambat terkecil (MIC) dari ekstrak kulit manggis dengankonsentrasi 3,9\% (B) dan konsentrasi $0 \%$ (A) berupa kontrol negatif.
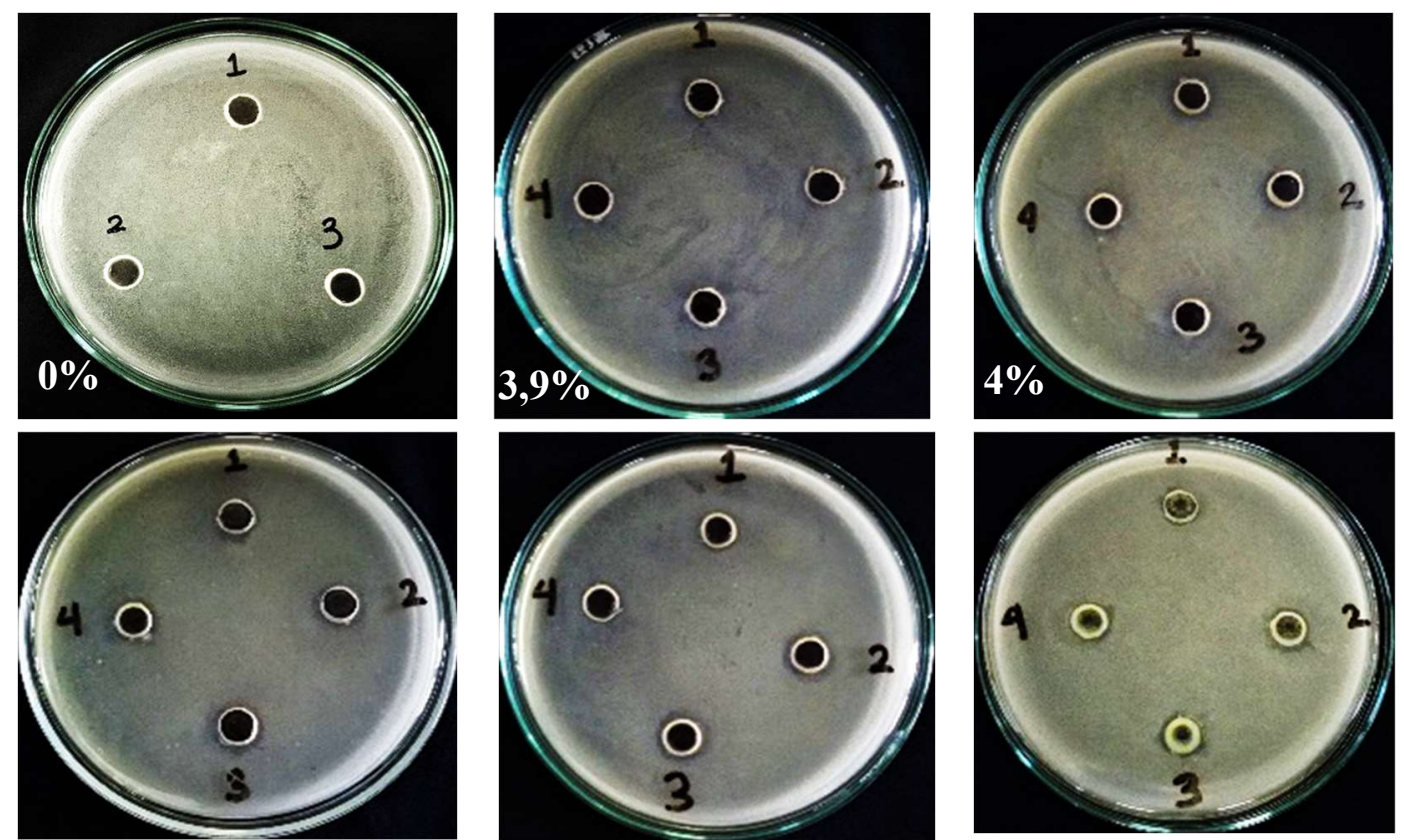

Gambar 4. Daya hambat terkecil dari ekstrak kulit manggis (Garcinia mangostana L.) pada bakteri E. coli (MIC) usia 24 jam pada 6 perlakuan.

Uji skrining fitokimia ekstrak kulit manggis ( $G$. mangostana L.)

Hasil uji skrining fitokimia ekstrak kulit manggis $(G$. mangostana L.) menunjukkan bahwa ekstrak kulit manggis positif mengandung alkaloid, fenolik, flavonoid, saponin, terpenoid dan ekstrak negatif mengandung steroid. Adapun hasil uji dapat dilihat pada Tabel 3. dan gambar uji pada Gambar 5.

Tabel 3. Hasil uji skrining fitokimia dari ekstrak kulit manggis (G. mangostanaL.).

\begin{tabular}{ccc}
\hline No & Jenis senyawa & Hasil uji \\
\hline 1. & Alkaloid & +++ \\
2. & Fenolik & + \\
3. & Flavonoid & + \\
4. & Saponin & +++ \\
5. & Terpenoid & ++ \\
6. & Steroid & - \\
\hline
\end{tabular}

Keterangan: Banyak (+++); Sedang (++); Sedikit (+); dan Tidak ada (-) 

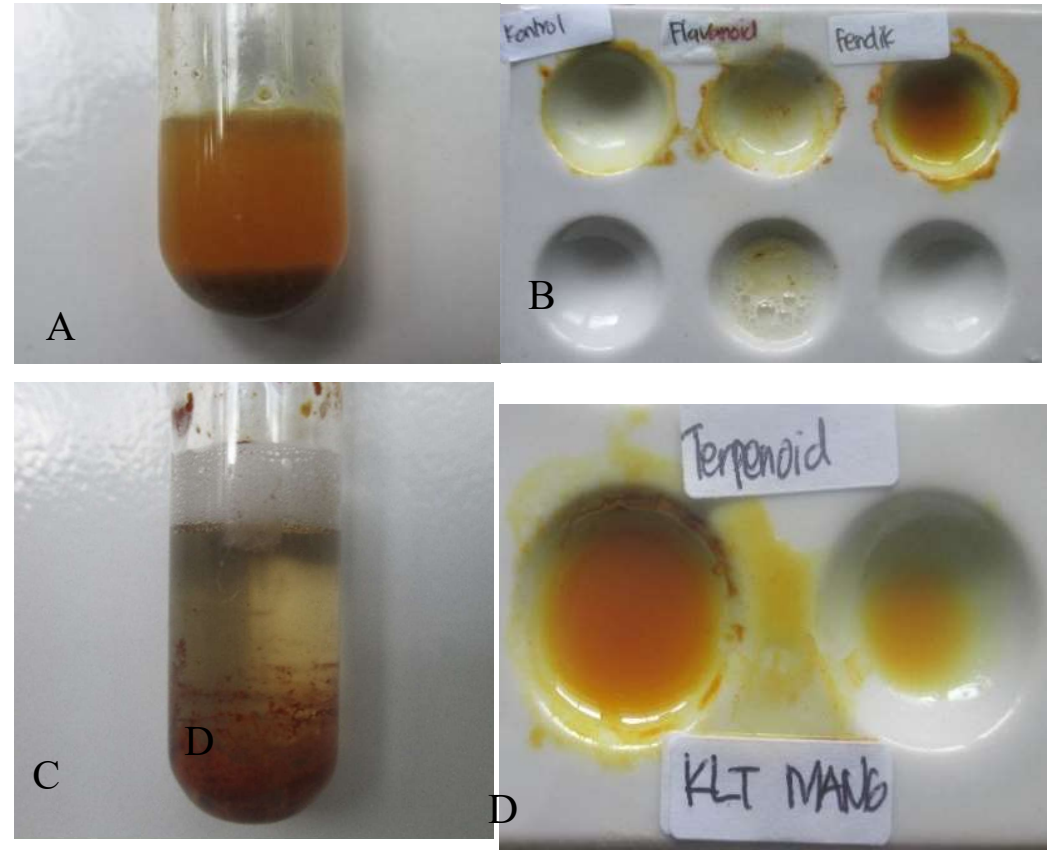

Gambar 5. Hasil uji skrining fitokimia dari ekstrak kulit manggis (G. mangostanaL.) dengan senyawa yang teridentifikasi, yaitu alkaloid (A); fenolik dan flavonoid (B); saponin (C); terpenoid (D).

\section{PEMBAHASAN}

Uji daya hambat ekstrak kasar kulit buah manggis (Garcinia mangostana L.) pada bakteri uji Escherichia coli

Berdasarkan hasil pengamatan terhadap uji antibakteri ekstrak terhadap bakteri $E$. coli, menunjukkan bahwa terdapat zona hambat terhadap pertumbuhan bakteri uji dengan diameter zona hambat yaitu rerata 1,48 $\mathrm{cm}$ pada masa inkubasi 24 jam dan $1,51 \mathrm{~cm}$ pada masa inkubasi 48 jam dengan zona hambat yang dikategorikan sebagai zona hambat kuat. Berdasarkan penggolongan Ardiansyah (2005), terdapat kreteria penilaian zona hambat suatu antibakteri dapat menghambat bakteri yaitu apabila diameter zona hambat lebih dari $2 \mathrm{~cm}$ dikatakan sangat kuat, $1-2 \mathrm{~cm}$ dikatakan kuat, $0,5-1 \mathrm{~cm}$ berukuran sedang, dan kurang dari $0,5 \mathrm{~cm}$ dikatakan lemah.Menurut Cushnie dan Lamb (2005), secara umum terdapat beberapa faktor yang mempengaruhi mutu daya hambat dari suatu ekstrak alam terhadap pertumbuhan bakteri, yaitu faktor kimia seperti jenis dan jumlah senyawa kimia, metode ekstraksi dan pelarut yang digunakan.

Faktor-faktor lingkungan seperti suhu udara, kelembapan relatif, radiasi matahari, angin, suhu tanaman, ketersediaan air, ketercukupan cahaya dalam proses fotosintesis sangat memengaruhi fungsi fisiologis, bentuk anatomis, dan siklus hidup tumbuhan (Melisa et al., 2015). Menurut Rusmiyati et al., (2010), faktor lingkungan sangat berpengaruh karena disaat pengaruh lingkungan yang ekstrim, tumbuhan manggis akan mengeluarkan senyawa berupa metabolit sekunder sebagai bentuk pertahanan diri.

Daya hambat terkecil (MIC) dari ekstrak kulit manggis (Garcinia mangostana L.) pada bakteri Escherichia coli

Konsentrasi minimun ekstrak kulit manggis yang mampu menghambat pertumbuhan bakteri uji yaitu pada konsentrasi 3,9\%. Efektifitas daya hambat ekstrak kulit manggis pada 6 perlakuan dan 4 ulangan menunjukkan bahwa ekstrak etanol kulit manggis ( $G$. mangostana L.) mampu menghambat pertumbuhan bakteri bakteri Escherichia coli dan berbeda nyata dengan kontrol $(\mathrm{P}<0,05)$.
Menurut Holetz et al. (2002), semakin kecil konsentrasi hambat minimum ekstrak menandakan semakin potensial ekstrak tersebut sebagai antibakteri, karena dengan konsentrasi kecil ekstrak sudah dapat menghambat dan membunuh bakteri.Menurut Agustin (2005), masing-masing konsentrasi ekstrak kulit buah manggis (G. mangostana L.) memiliki perbedaan pada zona hambat yang ditimbulkan. Ini menyatakan bahwa semakin tinggi kadar zat aktif (flavonoid, alkaloid dan terpenoid) pada ekstrak kulit buah manggis ( $G$. mangostana L.) maka semakin besar pula aktivitas daya antibakterinya. Hal ini dapat dilihat dari diameter zona hambat yang terbentuk, pada yang bersisi konsentrasi lebih tinggi memiliki diameter zona hambat lebih besar daripada konsentrasi yang lebih rendah. Ini menunjukkan, ada kecenderungan semakin tinggi konsentrasi ekstrak kulit buah manggis ( $G$. mangostana L.) maka zona hambat yang terbentuk semakin besar.

Seperti penelitian yang dilakukan oleh Muslichah et al., (2011), kulit buah manggis mampu menghambat pertumbuhan bakteri Stapylococcus aureus dan konsentrasi yang mampu menghambat pertumbuhan tersebut yaitu pada konsentrasi $5 \%, 10 \%, 20 \%, 40 \%$, dan $60 \%$. Dengan masing-masing diameter zona hambatnya sebesar 10,6 mm, 12,6 mm, 14,8 mm, $15 \mathrm{~mm}$, dan 15,8 $\mathrm{mm}$.

Berdasar penelitian yang dilakukan oleh Darmawansyih, (2014) terhadap kulit buah manggis (Garcinia mangostana L.) sebagai antifungi penyebab ketombe (Pityrosporum ovale) didapatkan simpulan bahwa kulit buah manggis (Garcinia mangostana L.) pada konsentrasi $100 \%$ memiliki efek antifungi Pityrosporum ovale yang setara dengan Ketokonazole $2 \%$.

Pada penelitian Palakawong et al.,(2010), ekstrak manggis (Garcinia mangostana L.) mampu menghambat pertumbuhan bakteri gram positif ( $L$. monocytogenes dan Staphylococcus aureus) dan bakteri gram negatif (E. coli dan Salmonella sp). Penelitian lainnya menunjukkan bahwa konsentrasi 35\% dan 30\% ekstrak kulit manggis (Garcinia mangostana L.) efektif dalam menghambat pertumbuhan Flavobacterium, Enterobacter (Yayang et al., 2013).

Penelitian dari Dodi dan Ika (2014) menyatakan ekstrak kulit buah manggis (Garcinia Mangostana L.) sebagai antibakteri terhadap bakteri Actinobacillus 
$\cap A \Delta J \begin{aligned} & \text { DIRECTORY OF } \\ & \text { OPEN ACCESS } \\ & \text { JOURNAISS }\end{aligned}$

actinomycetemberhasil menghambat pada $0,781 \%$ pada pengulangan ke-2 dan ke-3 dan 0,39\% pada pengulangan ke-1, sedangkan ekstrak kulit buah manggis berhasil membunuh bakteri Actinobacillus actinomycetempada konsentrasi $0,39 \%$.

\section{Uji skrining fitokimia ekstrak kulit manggis ( $G$. mangostana $\mathrm{L}$.)}

Uji skrining fitokimia yang bertujuan untuk mengetahui adanya golongan senyawa metabolit sekunder seperti alkaloid, fenolik, flavanoid, saponin, terpenoid, dan steroid. Pengamatan pada alkaloid dilakukan dengan reaksi pengendapan, Uji fenolik dan flavonoid dapat dilihat berdasarkan reaksi pembentukan warna, uji saponin berdasarkan pembentukan busa, sedangkan uji terpenoid dan steroid sama halnya dengan uji fenolik dan flavonoid dapat dilihat berdasarkan reaksi pembentukan warna. Hasil uji dapat diketahui bahwa ekstrak kulit buah manggis ( $G$. mangostana L.) memiliki beberapa senyawa metabolit sekunder yaitu alkaloid, fenolik, flavonoid, saponin dan terpenoid. Sedangkan steroid tidak terdapat pada kandungan senyawa dari ekstrak kulit buah manggis ( $G$. mangostana L.)

Menurut penelitian yang dilakukan Pasaribu and Bahri (2012), ekstrak etanol 96\% kulit buah manggis mengandung senyawa kimia golongan alkaloida, flavonoida, glikosida, saponin, tanin dan steroid/triterpenoid. Penelitian lain yang dilakukan Poeloengan dan Praptiwi (2010) menunjukan bahwa ekstrak etanol $70 \%$ mengandung komponen kimia alkaloid, saponin, tanin, fenolik, flavonoid, triterpenoid, steroid dan glikosida.

\section{SIMPULAN}

Ekstrak etanol kulit buah manggis (G. mangostana L.) efektif menghambat pertumbuhan bakteri Escherichia coli secara in-vitro, dimana efek antibakteri dari $100 \%$ konsentrasi ekstrak kulit manggis memiliki daya hambat yang kuat dengan Minimum Inhibitory Concentration (MIC) dari ekstrak kulit manggis terhadap bakteri Escherichia coli yaitu 3,9\%.Senyawa yang terkandung pada ekstrak etanol kulit manggis ( $G$. mangostana L.) adalah alkaloid, fenolik, flavonoid, saponin dan terpenoid.

\section{KEPUSTAKAAN}

Agustin, D. 2005. Perbedaan Khasiat Antibakteri Bahan Irigasi antara Hidrogen Peroksida 3\% dan Infusum Daun Sirih 20\% terhadap Bakteri Mix, Maj.Ked. Gigi. (Dent. J.). 38 (1):47.

Ardiansyah. 2005. Antimikroba Dari Tumbuhan (serial online). http://www.berita.iptek.com. Diakses tgl 25 Oktober 2016.

Cahyo, B. \& Agus. 2011. Manggis Budidaya dan Analisis Usaha Tani. hal. 79, Kanisius, Yogyakarta.

Cushnie, T.P.T., dan Lamb A.J. 2005. Antimicrobial Activity of Flavonoids. International Journal of Antimicrobial Agents. 26:343 356.

Darmawansyih. 2014. Khasiat Buah Manggis Untuk Kehidupan. Jurnal Al Hikmah. Makassar: UIN Alauddin Makassar. 1(15):61 - 64.
Dungir S.G. Dewa G., Katja dan Vanda S. 2012. Aktivitas Antioksidan Ekstrak Fenolik dari Kulit Buah Manggis (Garcinia mangostana L.). Jurnal Mipa Unsrat. 1(1): $11-15$.

Dodi, P., dan Ika A. 2014. Daya Antibakteri Ekstrak Etanol Kulit Buah Manggis (Garcinia mangostana L.) Terhadap Bakteri Actinobacillus actinomycetemcomitans. Jurnal Studi Pendidikan Dokter Gigi. 1(2): 1-8.

Holetz, F. B., Pessini, G. L., Sanches, N. R., Cortez, D. A. G., Nakamura, C. V., dan Dias Filho, B. P. 2002. Screening of some plants used in the Brazilian folk medicine for the treatment of infectious diseases. Memórias do Instituto Oswaldo Cruz. 97(7):10271031.

Melisa, R.T., Billy J.K., dan Michael A.L. 2015. Uji Daya Hambat Ekstrak Daun Sirsak (Annona muricata L.) terhadap Pertumbuhan Staphylococcus aureus Secara In Vitro. Jurnal Ilmiah Farmasi. Program Studi Pendidikan Dokter Gigi Fakultas Kedokteran, UNSRAT. 4(4):65 70.

Muslichah, Anggraini dan Waluyo. 2011. Uji Aktivitas Antibakteri Ekstrak Etil Asetat Kulit Buah Manggis (Garcinia mangostana L.) Terhadap Streptococcus mutans. Karya Ilmiah. Fakultas Farmasi Universitas Jember.

Noviardini P.U. 2010. Uji Aktifitas Antibakteri Alfa Mangostin Kulit Buah Manggis (Garcinia mangostana L.) Terhadap Bakteri Escherichia coli Multiresisten Antibiotik dan Bakteri Streptococcus sp. Skripsi Fakultas Farmasi. Universitas Muhammadiyah Surakata.

Palakawong, C., Sophanodora, P., Pisuchcen, S, dan Phongpaichit, S. 2010. Antioxidant and antimicrobial activities of crude extracts from mangosteen (Garcinia mangostana L) parts and some essential oils.IFRJ.17: 583-589.

Pasaribu, F.P.S dan Bahri S. 2012. Uji Ekstrak Etanol Kulit Buah Manggis (Garicinia mangostana L.) terhadap Penurunan Kadar Glukosa Darah. Journal of Pharmaceutics dan Pharmacologi. 1(1) : 1-8.

Poeloengan, M. dan Praptiwi. 2010. Uji Aktivitas Antibakteri Ekstrak Kulit Buah Manggis. Media Litbag Kesehatan. 20(2): 12 - 18.

Qosim, W.A. 2007. Kulit Buah Manggis sebagai Antioksidan. http//anekaplanta.wordpress.com/2007/12/ 26/kulitbuahmanggissebagaiantioksidan/. Diakses tgl 25 Oktober 2016.

Rusmiyati, I., Husain D.R., Alam G. 2010. Bioaktivitas Ekstrak Metanol Daun Muda Sirsak Annona muricata L. sebagai Antibakteri Terhadap Staphylococcus aureus dan Propionibacterium acnes. Jurnal. 


\section{DIRECTORY OF
OPEN ACCESS}

Makassar: Universitas Hasanuddin.

4(1):35-40.

Yayang, M., Khotimah, S., dan Diba, F. 2013. Aktivitas Antibakteri Kulit (Garcinia mangostana L.) Terhadap Pertumbuhan Flavobacterium dan Enterobacter dari Coptotermes curvignathus Holmgren. Protobiont. 2(1). 7-11. 